\title{
PENGENALAN DAN PELATIHAN BAHASA PEMOGRAMAN ANDROID PADA SISWA SMK NEGERI 1 AIR JOMAN - KISARAN
}

\author{
Agus Suryadi $^{1}$, Akmal Nasution ${ }^{2}$, Eka Lia Febrianti ${ }^{3}$ \\ ${ }_{1,2,3}$ Program Studi Sistem Informasi, STMIK Royal \\ email:1 agussuryadi2013@gmail.com, ${ }^{2}$ nst.akmal@gmail.com, ${ }^{3}$ ekalia88@gmail.com
}

\begin{abstract}
The community of society is one of main activities required by a lecture as part of the tri dharma which aimed to apply and implement the scientific competence a lecturer to contribute positively especially for society needs. Vocational High School is a vocational school that is required to be ready to enter the world of work, therefore the SMK graduates are required to have the skills and knowledge that will be used in the workplace. Students of vocation especially in the majors of Software Engineering must have skills in computer science, such as programming skills. In the 2013 curriculum used by SMKN1 Air Joman, there are already programming subjects, but still local content and yet the discovery of mobile programming. Though mobile programming is currently one of the most popular programming, especially Android. This is not separated from the rapid development of the Android operating system, so people are competing to make the application.
\end{abstract}

Keywords:programming, mobile programming, android

\begin{abstract}
Abstrak: Pengabdian kepada masyarakat merupakan salah satu kegiatan wajib yang harus dilaksanakan oleh seorang dosen sebagai bagian dari tri dharma perguruan tinggi yang bertujuan untuk menerapkan dan mengimplementasikan kompetensi keilmuan yang dimiliki guna memberikan kontribusi positif bagi kebutuhan masyarakat. Sekolah Menengah Kejuruan (SMK) merupakan sekolah kejuruan yang dituntut untuk siap masuk ke dunia kerja, maka dari itu lulusan SMK diharuskan mempunyai Skill dan pengetahuan yang akan dipergunakan dalam dunia kerja. Siswa SMK terutama pada jurusan Rekayasa Perangkat Lunak harus memiliki keterampilan dalam ilmu komputer, seperti keterampilan programming. Pada kurikulum 2013 yang digunakan oleh SMKN1 Air Joman, sudah ada mata pelajaran programming, tapi masihbersifat muatan lokal dan belum ditemukannya pemrograman mobile. Padahal pemrograman mobile saat ini menjadi salah satu pemrograman yang paling diminati, khusunya Android. Hal ini tidak lepas dari pesatnya perkembangan sistem operasi Android tersebut, sehingga orang berlomba - lomba untuk membuat aplikasinya.
\end{abstract}

Kata kunci:pemrograman, pemrograman mobile, android

\section{PENDAHULUAN}

Lulusan Sekolah Menengah Kejuruan (SMK) dituntut untuk siap masuk ke dunia kerja, maka dari itu lulusan SMK diharuskan mempunyai Skill dan pengetahuan yang akan dipergunakan dalam dunia kerja jika ingin bersaing untuk mendapatkan pekerjaan. Siswa SMK terutama pada jurusan Rekayasa Perangkat Lunak harus memiliki keterampilan dalam ilmu komputer, baik dibidang programming, multimedia, maupun jaringan. Pada kurikulum 2013 yang dipakai sekarang oleh siswa SMKN1 Air Joman kisaran, 
Available online at http://jurnal.stmikroyal.ac.id/index.php/jurdimas

sudah terdapat mata pelajaran programming, tetapimasih bersifat muatan lokal dan jenis pemograman yang dipakai tergantung kepada guru yang mengajarkan mata pelajaran tersebut.

Android adalah sebuah sistem operasi pada smartphone yang bersifat terbuka dan berbasis pada sistem operasi Linux. Android bisa digunakan oleh setiap orang yang ingin menggunakannya pada perangkat mereka. Android menyediakan platform terbuka bagi para pengembang untuk menciptakan aplikasi mereka sendiri yang akan digunakan untuk bermacam peranti bergerak. Kelebihan dari android adalah sifatnya yang opensource dan mudah dikembangkan, apalagi untuk sekarang pengguna android sudah sangat termasuk siswa-siswa SMK, dengan demikian para siswa dapat membangun dan mengembangkan sebuah aplikasi android dan menerapkannya pada perangkat masing-masing sehingga bisa digunakan sesuai kebutuhan dan tidak menutup kemungkinan untuk bisa dikomersilkan.

Banyak sumber pembelajaran yang Maksud dari kegiatan pengabdian ini adalah melaksanakan Tri Dharma Perguruan Tinggi berupa Pengabdian Kepada Masyarakat sebagai pengamalan ilmu pengetahuan, teknologi kepada siswa SMK Negeri 1 Air Joman oleh dosen STMIK Royal Kisaran (terlampir). Tujuan yang ingin di capai dalam kegiatan ini adalah memberi pemahan pada siswa pentingnya mempunyai keahlian khusus, seperti : siswa mengenal dan mampu mengimplementasikan hasil dari pemrograman android untuk jenjang karir kedepannya dan lebih mengembangkan kreatifitas dan pemikiran sehingga bisa diterapkan di dunia kerja nantinya.

\section{METODE}

Tingkat keberhasilan program tersebut dapat dilihat dari tingkat pemahaman siswa peserta pelatihan terhadap materi yang disampaikan. Strategi yang digunakan untuk mencapai pemahaman siswa mengenai pengenalan dan pelatihan pemrograman android tersebut adalah dengan menerapkan dua metode yaitu metode pelatihan dan metodesimulasiipteks.

Metode pelatihan yaitu metode yang digunakan untuk kegiatan yang melibatkan penyuluhan tentang substansi kegiatan yang disertai dengan demonstrasi atau percontohan untuk realisasi dan pelatihan dalam pengoperasian sistem atau peralatan.Dalam kegiatan ini berarti kegiatan penyuluhan tentang android dengan pemaparan materi pengenalan pemrograman android. Memberikan pemaparan tentang pengoperasian tools pendukung yang digunakan untuk pemrograman android.

Metode Simulasi pteks yaitu metode yang digunakan untuk kegiatan yang karya utamanya adalah sistem informasi atau sejenisnya.Dalam kegiatan pengabdian ini berarti dilakuakan praktek programming android secara langsung, bagaimana cara membuat sebuah aplikasi android sederhana, mulai dari desain hingga tahap logika program, sehingga menghasilkan sebuah file yang siap diinstal atau dipasang diperangkat mobile siswa peserta pelatihan.

\section{PEMBAHASAN}

Pembahasan dalam kegiatan pengabdian masyarakat mencakup materi pokok tentang android.Secara garis besar materi bahasan mengenai sistem operasi mobile, android, dan pengembangan aplikasi android dengan android studio yang dijelaskan dibawah ini.

Membuat Aplikasi Android menggunakan bahasa pemrograman java. Tidak semua fitur java yang ada digunakan akan tetapi sebagian dari java yang sering disebut dengan Dalvik Virtual 
Vol. 1, No. 2, Jul 2018, hlm. 1 - 4

ISSN 2614-7912 (cetak)

ISSN 2622-3813 (online)

Available online at http://jurnal.stmikroyal.ac.id/index.php/jurdimas

Machine. Beberapa bagian kecil dari framework Android menggunakan bahasa XML untuk scripting-nya.Beberapa istilah yang populer dalam pemrograman android seperti Activity, merupakan container untuk User Interface (UI) dalam pemrograman android.Sebuah Aplikasi Android terbangun dari satu atau beberapa Activity.Intents, merupakan sistem pesan utama yang menjalankan Android.Intent terdiri dari action yang harus dijalankan (Tampil, Ubah, Dial, dan lain-lain) dan data.Intent digunakan untuk memulai aktivitas dan komunikasi antar bagian dari sistem Android.Suatu aplikasi dapat mengirimkan atau menerima intent.

Pemrograman Android dapat menggunakan Android Studio yang merupakan Lingkungan Pengembangan Terpadu - Integrated Development Environment (IDE) untuk pengembangan aplikasi Android, berdasarkan IntelliJ IDEA. Selain merupakan editor kode IntelliJ dan alat pengembang yang berdaya guna, Android Studio menawarkan fitur lebih banyak untuk meningkatkan produktivitas saat membuat aplikasi Android, misalnya sistem versi berbasis Gradle yang fleksibel, emulator yang cepat dan kaya fitur, lingkungan yang menyatu untuk pengembangan bagi semua perangkat Android, instant Run untuk mendorong perubahan ke aplikasi yang berjalan tanpa membuat APK baru, template kode dan integrasi GitHub untuk membuat fitur aplikasi yang sama dan mengimpor kode contoh, alat pengujian dan kerangka kerja yang ekstensif, alat Lint untuk meningkatkan kinerja, kegunaan, kompatibilitas versi, dan masalah-masalah lain, dukungan $\mathrm{C}++$ dan NDK, dukungan bawaan untuk Google Cloud Platform, mempermudah pengintegrasian Google Cloud Messaging dan App Engine.

Untuk mengimplementasikan program aplikasi yang telah dirancang, maka diperlukan sebuah alat bantu berupa komputer, yang mana untuk mengoperasikan komputer itu sendiri yang memerlukan tiga buah komponen pendukung seperti hardware, software, dan brainware. Pembuatan proyek android sederhana dapat dilihat pada gambar berikut.

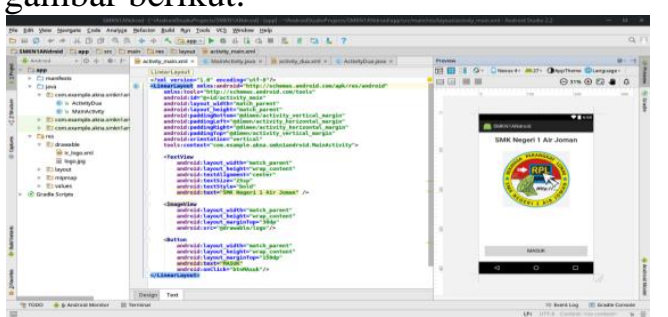

Gambar 1 Desain Tampilan Awal

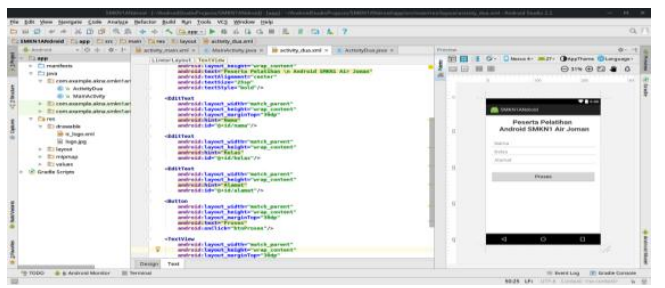

Gambar 2 Desain Halaman Form Input

Hasil pembuatan program android akan di build dengan ekstensi .apk yang siap dipasang di perangkat mobile siswa peserta. Tampilan akhir program sederhana yang dibuat terlihat pada gambar berikut.

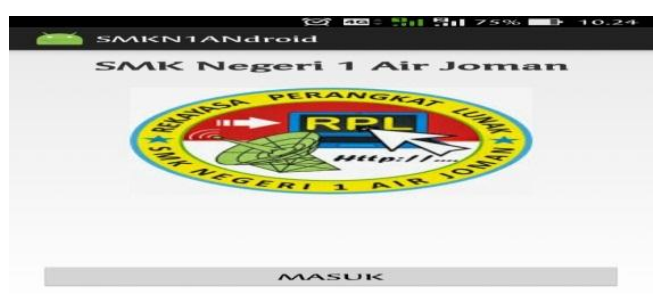

Gambar 3 Halaman Depan

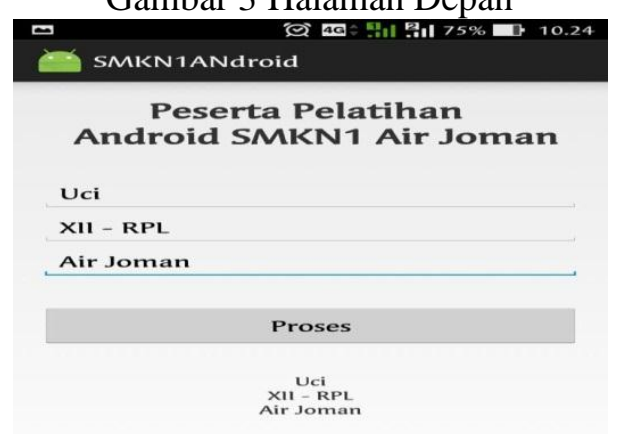

Gambar 4 Halaman Input 
Vol. 1, No. 2, Jul 2018, hlm. 1 -4

ISSN 2614-7912 (cetak)

ISSN 2622-3813 (online)

Available online at http://jurnal.stmikroyal.ac.id/index.php/jurdimas

Kegiatan yang berlangsung selama 2 hari yang dimulai dengan pemaparan materi di hari pertama dan pelatihan praktik pemrograman android dihari kedua didokumentasikan dalam foto-foto sebagai berikut.

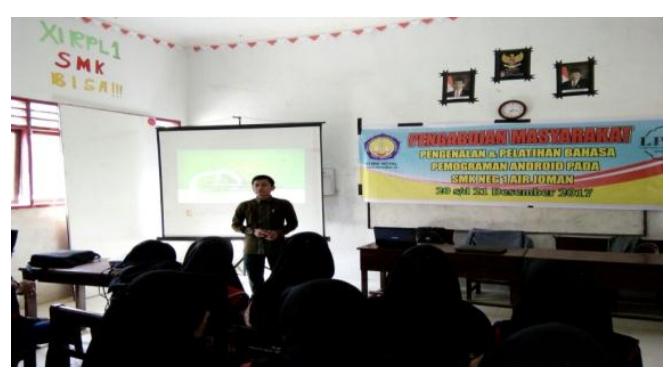

Gambar 5 Pemaparan Materi

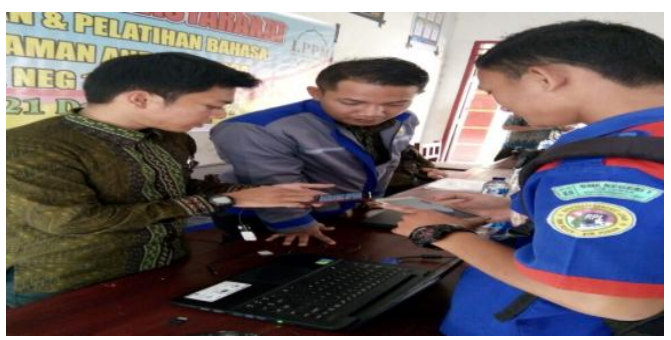

Gambar 6 Kegiatan Pelatihan

\section{SIMPULAN}

Kegiatan pengabdian pada

SMKN1 Air Joman merupakan kegiatan kampus yang menitikberatkan pada kegiatan pengenalan dan pelatihan pemrograman android.Sasaran kegiatan tersebut adalah siswa beserta guru di sekitar SMKN 1 Air Joman Kisaran.Kegiatan ini menggunakan metode pelatihan dan simulasi ipteks yang mengacu pada tujuan kegiatan, yaitu menambah pemahaman dan kemampuan peserta dalam pemrograman android. Hasilnya melalui kuisioner yang dibagikan, menunjukkan bahwa pemahaman mengenai pemrograman android para peserta pelatihan mengalami peningkatan selama dua hari kegiatan berjalan.

\section{UCAPAN TERIMA KASIH}

Ucapan terimakasih disampaikan kepada semua kalangan yang terlibat dalam kegiatan pengabdian ini. Kepada Kepala Sekolah SMKN 1 yang telah memberikan izin dan tempat untuk mengadakan pengabdian dan kepada ketua yayasan STMIK Royal kisaran yang telah bersedia memberikan dana untuk kelancaran kegiatan pengabdian masyarakat ini. Tidak lupa pula kepada LPPM STMIK Royal dan dosen-dosen lainnya yang terlibat sehingga kegiatan pengabdian masyarakat ini berjalan sebagaimana mestinya.

\section{DAFTAR PUSTAKA}

Hakiky Fifin, Ichwan,M. Agustus(2016), "Pengukuran kinerja goodreads application programming interface (api) pada aplikasi mobile android". Jurnal informatika.Vol 2, No. 2.

Luthfi, Emha, Taufiq,.(2016) "Dasar pemrograman Android".Akses tanggal 29 november2016. repo.unnes.ac.id/android/modul_a ndroid.pdf.

Sapta, A. (2016). Publication of The Assessment Learning Outcomes Through Social Media. The 1st Annual International Seminar on Transformative Education and Educational Learship (pp. 480483). 